\title{
Christmas 1941
}

\author{
Trish Groves
}

On Christmas Eve 1941 Lieutenant Thurstan (Tony) Brewin $^{\star}$ finally located his regiment in the North African desert south east of Benghazi. The colonel who welcomed him was delighted not only by the accompanying cargo of Christmas puddings and mince pies but also because Brewin's arrival meant that he would no longer be the shortest officer in the 11 th Hussars.

Just five weeks later the diminutive Brewin was wounded and captured by German troops. When repatriated by the Red Cross in 1943, via Italian hospitals and a prison camp, he was informed that the War Office was "terminating his employment because of ill health." The formal letter did not even mention that he had been wounded in action, let alone acknowledge that he had lost a leg at just 20.

The Ministry of Information was pleased to employ Brewin, however, as a speaker to improve morale in munitions factories. He could start as soon as a quick identity check had been made. This, explained the man from the ministry, was necessary because the best speaker on the circuit had just been exposed as a lifetime landlubber and his rousing tales of being torpedoed had rather lost their edge.

From the notes that Brewin used for his talks for the ministry and the Red Cross comes this account of being wounded and captured.

Desert nights can be cold and it seemed even more bitter than usual when we climbed into our three armoured cars just before dawn on Thursday 29 January. As we set off towards the enemy Corporal Nottingham bent down to adjust the piece of cardboard which helped to stop the draught from a hole in the armour plate of the turret. Some weeks previously by a tragic error (all too common in mobile desert warfare) a shell from one of our own tanks had torn through that hole and shattered the legs of a young troop leader who had died soon afterwards.

On the skyine, five or six miles off, we could see a big enemy concentration round Msus airfield. But the squadron leader told us to wait for further orders.

Everything was quiet and peaceful and we went off on our own to investigate a deserted truck about a mile away. We were pleased to find a little tinned food and a fine pair of German gauntlets. Suddenly my driver shouted and pointed south. Moving fast over the sand towards the other two cars were two vehicles. One, with a long black barrel, was clearly a German $88 \mathrm{~mm}$. From the earphones hanging over the edge of the turret came an order "Go forward and machine gun."

For light armoured cars an attack on a German 88 was not normally a thing to be recommended, but I was in a good position to shoot up the unprotected crew from the rear and force them to withdraw. In any case we were all heartily sick of retreating from an enemy who seemed to be having everything his own way. As soon as we were within range I gave the order to fire but after a couple of bursts a round failed to extract and the light machine gun jammed. I grabbed a cleaning rod and, climbing out on to the turret, managed to clear the obstruction in the barrel.

We began to close in at full speed and Nottingham opened fire. I could see our tracer flowing swiftly into the target in long savage bursts. The German fire was quickly silenced. But as we closed in to within 250 yards the small Besa jammed again and I then made the fatal mistake of wrestling with it instead of reloading the heavier $15 \mathrm{~mm}$. This gave the remaining enemy crew their chance. With a sudden paralysing

${ }^{\star}$ Dr Thurstan Brewin, FRCP, was consultant in radiotherapy and oncology in Glasgow 1961-87.

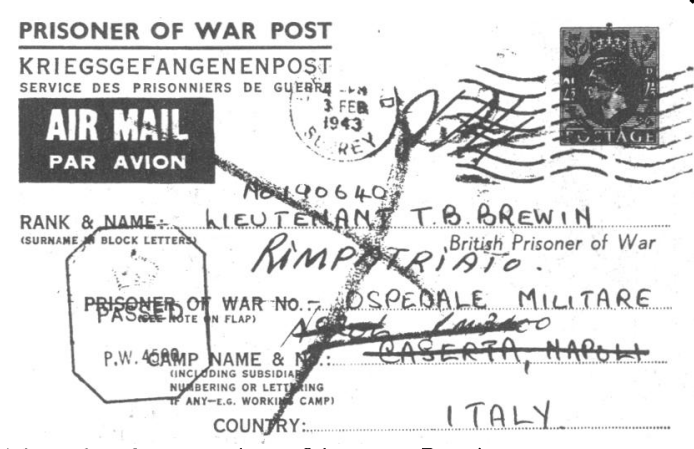

A letter from home to prisoner Lieutenant Brewin

shock the turret filled with smoke, somebody cried out in pain, my left leg went numb. Jim Nottingham called "I can't move, Sir, my legs have gone."

Somehow we got him out and laid him on the sand. One leg was severed completely just below the knee, the other was terribly smashed. In a ridiculously calm voice I asked him how he felt and his dead white face replied "Not so bad." I had been hit in the knee and Robinson, my driver was wounded in the hand. . .

It was dark when they carried me to a small German ambulance in which I was to make the first stage of a 600 mile journey to Tripoli. When I came to we had arrived at a German field dressing station near Agedabia. In excellent English a doctor with kind eyes examined me and said that my knee should be operated on as soon as possible. But he was sorry - he had to proceed to Benghazi and hand all British wounded to the Italians.

\section{Pain in the amputated leg}

The rest of the journey was done in four stages via Agedabia, Agheila, Cirte, and Misurata. Each stage consisted of five or six hours rattling and bumping in an overcrowded ambulance without blankets and food, and frequently without water. Morphia was not given and at the end of the day, when the stretchers were carried into Red Cross tents, resistance to pain was at its lowest. It was then that we were taken one by one to the operating tent where the real pain was still to come.

I was luckier than most with regard to the lack of anaesthetics. But at Misurata the doctor explained to me that he was going to cut open the back of my knee for a small operation and that, unfortunately, my heart was "too weak to allow the use of any anaesthetic." Four Italians then held me down while the interpreter held a mug of "cognac" to my lips and gave a running commentary on the course of the operation in lurid American slang.

Things improved when we reached Bu Setta Hospital at Tripoli. Compared with previous field hospitals it was like a paradise. But hardly any attempt was made to get us clean and, owing to a shortage of urine bottles, eight of us were reduced to sharing a rusty jam tin. Next morning three of usa captain in the gunners, a RAF pilot, and I-each had a leg amputated. I was the last and had a long wait in an adjoining room where I could plainly hear the previous operation in progress. For the rest of the day the pain was pretty bad, not in the stump but quite distinctly in the toes, ankle, and knee of the amputed leg. So vivid was this impression that I found myself constantly raising the bedclothes to look incredulously at the short length of white bandage stained with red that was all that remained of my leg.

We soon made many friends among the Italians, above all Sister Anna. She was the old nun in charge of our wing who looked after us with unfailing kindness. She loved to bring us specially cooked eggs and sweets and oranges and hand them 
to us with a sweet smile, pinching our cheeks as if we were children. We grew very fond of her and it was bitter news to hear, months later, that she had been killed in a RAF raid. It was another old nun rather like her who assured us that we were not to worry because our legs had been properly buried in the local cemetery and that "the Lord would give them back" to us when we died.

Interviewed recently Thurstan Brewin described how he felt when he finally crossed the Mediterranean to Caserta Hospital near Naples. There were British doctors at work and, best of all, British Red Cross parcels, cigarettes, and books. Brewin officially ran the prisoners' library-unofficially he also produced a secret news sheet with headline stories of allied successes gleaned from denials in local newspapers. His role as librarian is remembered by Captain Brian Stone in Prisoner from Alamein.

During the six days I was there I was able to read five books. They were brought to the bedside by an officer with one leg who combined a great knowledge of books with an extraordinary ability to carry large numbers of them whilst walking with crutches. He could run almost as fast as a complete man by hopping and using his crutches, despite being wounded only seven months before.

For Brewin a year in Italy passed painfully slowly even though he made many good friends from all parts of the world; learnt a lot of Italian, a little German, some French, and several card games; and enjoyed the sun and the beauty of the countryside. The whispered conversations after dark with an Italian doctor's daughter in a window some 10 feet below the ward, and the smuggled chocolate that resulted, were both a help. But Brewin hated the captivity, did not appreciate having his head shaved, and got tired of macaroni floating in greasy soup.

\section{From prisoner to pirate}

Some of the books Brewin enjoyed in captivity were on basic science, a subject he had barely touched at school-it was not then essential for entry to medical school. But while helping the captive doctors in Italy he was inspired to ask "Can I be a doctor with only one leg?" Presumably the answer was yes, because soon after his return to England in 1943 he started as a student at Guy's Hospital.

Apart from the doodlebug flying bombs that fell on London during his exams, Brewin remembers medical school as great fun and probably little different from student life today. And disability did not hold him back when he qualified. At Guy's he and his fellow houseman George Scott were famed for their high speed descent of five flights of stairs - one running, the other hopping. Brewin's boss Sir Rowan Boland had lost an eye in the first world war and was quite an inspiration. On one memorable ward round the doctors, one with a wooden leg, the other with a black eye patch, found themselves listening to a former merchant seaman's paranoid delusions. He thought he was being pursued by pirates. "Let's do this properly," said Boland, "on the next ward round I'll have a parrot on my shoulder."

\section{It helps to remember faces}

\section{Francis Saa-Gandi}

My wife and I arrived in Trinidad about six months ago from England. We had had a choice of going to Sierra Leone or Trinidad or staying in England. The abundant sunshine and the political stability in this Caribbean island were irresistible.

Friday 27 July 1990 was like any other day. It was the rainy season but the day was dry, sunny, bright, and there was not a cloud in the sky. This Caribbean weather was to change suddenly at $6 \mathrm{pm}$ on "black Friday" in Port of Spain, the capital.

Two hours earlier I had been in the library refreshing my memory on managing a patient with long standing dysphagia due to achalasia. I was telephoned by my house officer, who told me that a 25 year old woman with a mutilated right forearm had been admitted after a road traffic accident. All attempts to save the arm failed. While we were dressing the stump the theatre sister walked into the operating theatre and in her usual joking manner announced that the television and radio stations had been seized by the Jamaat Al Muslimeen (Group of Moslems) people. All those present burst out laughing but she just smiled and left the theatre.

Less than five minutes later she returned to say that the Central Police Station was on fire. After completing surgery I joined her on the balcony to see thick smoke coming from the station. This was confirmed by a broadcast over the radio and on television by the Imam Yasin Abu Bakr. What had seemed a fantasy became a reality. Abu Bakr, a former police corporal, is the leader of the Jamaat Al Muslimeen people. This group of Moslems has existed in Trinidad since 1976. The Imam declared that he had overthrown the present government with the help of Allah. He also said that he held the parliamentarians as hostages in the Red
House, the seat of government, and further hostages in the local television station.

Having looked down the barrel of a gun and lived through a coup d'état in Sierra Leone, I was going to do everything within my power to avoid facing a man or woman with a gun again. After completing the theatre and ward work I therefore drove home, which is 18 kilometres from the Port of Spain General Hospital.

At $1130 \mathrm{pm}$ I had a telephone call from the house officer requiring my help in hospital as many seriously injured people had been brought in from the city. An ambulance was sent to collect me. We sped through the suburbs at 100 kilometres an hour. The driver went through an unmanned barricade with a no entry sign. I did not protest and wrongly assumed that he had previous arrangements with the appropriate authorities. Suddenly, a man appeared from the dark and flagged the van to stop, and within minutes we were surrounded by about 20 men in plain clothes with guns and knives. There was no leader and everybody gave orders. The driver and his mate had identification cards with them but I had none, only my stethoscope. My captors immediately assumed that I had kidnapped the other two men. I was dragged out of the van and ordered to lie face down with my hands behind my head at gunpoint. It did not help to be an obvious foreigner especially when it was rumoured that $\mathrm{Abu}$ Bakr had outside help.

As my life flashed before me I recognised one of the policemen, who had been a patient in one of our wards. I seized the opportunity and said to him, "You're the man we treated with gunshot wounds about two months ago on ward 14. Don't you remember me as your surgeon?" Indeed, the man recognised my face 